\title{
HUBUNGAN PERSEPSI DENGAN PERILAKU PENCEGAHAN PENULARAN TUBERKULOSIS PARU DI PUSKESMAS PERAK TIMUR TAHUN 2019
}

Firda Safira Ali, Setiawan, Ngadino

Jurusan Kesehatan Lingkungan Poltekkes Kemenkes Surabaya Email : firdasfra13@gmail.com

\begin{abstract}
ABSTRAK
Tuberculosis masih merupakan masalah kesehatan di Indonesia dan di dunia. Tuberculosis paru disebabkan oleh infeksi bakteri Mycobacterium tuberculosis melalui percikan dahak pasien dengan tuberkulosis Basil Tahan Asam positif (BTA positif). Penularan TB dapat dipengaruhi oleh beberapa faktor seperti perilaku buruk. Bagaimana upaya mencegah penularan TB paru pada pasien yang berhubungan dengan perilaku kesehatan dapat menggunakan teori Health Belief Model (HBM). Provinsi Jawa Timur menempati urutan kedua dalam kasus TB pada 2017. Adapun Kota Surabaya, menempati posisi pertama dalam jumlah pasien TB tertinggi di Jawa Timur. Pusat Kesehatan Perak Timur adalah Puskesmas dengan jumlah pasien Tuberculosis terbanyak di Surabaya. Penelitian ini bertujuan untuk mengetahui hubungan antara persepsi dan perilaku pencegahan penularan Tuberculosis pada pasien Tuberculosis.

Penelitian ini adalah penelitian kuantitatif dengan metode desain analitik cross sectional. Sampel dalam penelitian ini adalah pasien tuberkulosis paru, berjumlah 62 orang dari populasi 74 orang. Teknik pengambilan sampel menggunakan teknik probability sampling. Teknik pengumpulan data dengan menggunakan kuesioner. Analisis data yang digunakan dalam penelitian ini adalah analisis univariat dan analisis bivariat menggunakan uji Chi-Square.

Hasil penelitian menunjukkan hubungan antara persepsi kerentanan ( $\mathrm{p}$-value $=$ $0,045)$, keseriusan ( $p$-value $=0,033)$, manfaat $(p$-value $=0,045)$ dengan perilaku pencegahan penularan TB paru. Sedangkan untuk variabel persepsi hambatan tidak memiliki hubungan dengan perilaku preventif. Diharapkan bahwa sosialisasi dan konseling akan lebih intensif untuk pasien dengan TB paru dan di samping pasien dengan TB paru dapat mencegah penularan TB paru.
\end{abstract}

Kata kunci: Tuberculosis, perilaku pencegahan, HBM

\section{PENDAHULUAN}

TB Paru masih menjadi masalah kesehatan di Indonesia dan di dunia. TB Paru adalah penyakit menular yang disebabkan olehbakteri Mycobacterium tuberculosis. Penularan TB Paru melalui udara yang mengandung droplet dari penderita TB Paru terutama pasien BTA+. TB termasuk dalam 10penyakit tertinggi penyebab kematian menurut WHO. Pada tahun 2016 diperkirakan 10,3juta penderita TB meninggal negative HIV. Sesuai dengan data WHO Global Tuberculosis Report 2016 Indonesia menempati posisi kedua.

Tuberculosis merupakan penyakit infeksi yang disebabkan bakteri Mycobacterium tuberculosis. Bakteri ini berbentuk batang, dengan Panjang 1-
$4 \mathrm{~mm}$ dan tebal $0,3-0,6 \mathrm{~mm}$. bakteri ini disebut Basil Tahan Asam karena dapat tahan pencucian asam dan alcohol dalam keadaan kering dingin bersifat dorman dan aerob.

Penularan penyakit Tuberkulosis dapat dipengaruhi oleh perilaku penderita Tuberkulosis beberapa domain perilaku seperti pengetahuan, sikap dan tindakan. Factor-faktor tersebut berpengaruh terhadap status kesehatan dan program kesehatan terutama dalam penanggulan dan penegahan Tuberkulosis.

Persepsi merupakan bagaimana seseorang memberikan makna terhadap stimulus. Ditinjau dari teori Health Belief Model (HBM) yang dikenalkan oleh 
Becker \& Rosenstock dalam Glanz, et.al., perilaku kesehatan pada individu dapat dipengaruhi beberapa komponen, seperti persepsi kerentanan, persepsi keseriusan, persepsi manfaat dan persepsi hambatan. HBM digunakan untuk analisis hubungan perubahan perilaku dengan mengetahui faktor yang menentukan dari perilaku pencegahan dan pencarian pengobatan.

Berdasarkan survey pendahuluan yang telah dilakukan dengan mengumpulkan data laporan tahunan Dinas Kesehatan Kota Surabaya tahun 2016 dan 2017 untuk jumlah kasus Tuberkulosis tertinggi di wilayah kerja Puskesmas Perak Timur. Selain itu juga dari hasil wawancara dengan petugas program pemegang TB disebutkan bahwa terdapat kasus kontak rumah pada penderita TB Paru di wiliyah kerja Puskesmas Perak Timur. Maka dari itu penelitian ini bertujuan untuk untuk mengetahui hubungan antara persepsi dengan perilaku pencegahan penularan Tuberkulosis Paru di wilayah kerja Puskesmas Perak Timur.

\section{METODE PENELITIAN}

Jenis penelitian dalam penelitian ini adalah analitik kuantitatif dengan metode cross sectional. Variabel independen dalam penelitian ini adalah persepsi kerentanan, persepsi keseriusan, persepsi manfaat, dan persepsi hambatan. Variabel dependen pada penelitian ini perilaku pencegahan penularan TB Paru. Populasi dalam penelitian ini adalahpasien TB Paru di Puskesmas Perak Timur sebanyak 74orang. Sampel dalam penelitian ini adalah 62orang dengan metode probability sampling.

Alat pengumpul data yang digunakan untuk mengukur persepsi pasien adalah kuisioner sesuai dengan teori Health Belief Model dan untuk mengukur perilaku menggunakan kuisioner. Kuisioner yang digunakan telah diuji validitas dan reliabilitas. Nilai validitas r-table lebih dari 0,361 sedangkan untuk reliabilitas lebih dari nilai Cronbach's alpha 0,60.

\section{HASIL DAN PEMBAHASAN}

Analisis Univariat

Perilaku Pencegahan

Tabel 1

Frekuensi perilaku pencegahan penularan

\begin{tabular}{lcc}
\hline $\begin{array}{c}\text { Perilaku } \\
\text { Pencegaha } \\
\text { n }\end{array}$ & Frekuensi & $\begin{array}{c}\text { Persentas } \\
\text { e (\%) }\end{array}$ \\
\hline Kurang Baik & 39 & 62,9 \\
\hline Baik & 23 & 37,1 \\
\hline Total & $\mathbf{6 2}$ & $\mathbf{1 0 0}$ \\
\hline
\end{tabular}

Diketahui bahwa responden yang

memiliki perilaku kurang baik 62,9\% lebih banyak dibandingkan responden yang berperilaku baik. Perilaku pencegahan penularan kurang baik dapat dikarenakan kurangnya perilaku responden dalam menutup mulut dan hidung ketika batuk atau bersin, menggunakan masker, atau meludah sembarangan.

\section{Persepsi Kerentanan}

Tabel 2

Frekuensi persepsi kerentanan

\begin{tabular}{|c|c|c|}
\hline $\begin{array}{c}\text { Persepsi } \\
\text { Kerentanan }\end{array}$ & $\begin{array}{c}\text { Frekuen } \\
\text { si }\end{array}$ & $\begin{array}{c}\text { Persentase } \\
(\%)\end{array}$ \\
\hline Kurang Baik & 11 & 17,7 \\
\hline Baik & 51 & 82,3 \\
\hline Total & 62 & 100 \\
\hline Dapat & diketahui & bahwa \\
\hline
\end{tabular}

kerentanan kurang baik lebih sedikit $17,7 \%$ dibandingkan yang memiliki persepsi baik. Berdasarkan penelitian yang telah dilakukan lebih banyak responden yang merasa dirinya rentan terhadap penyakit dibanding dengan yang merasa tidak rentan. Semakin rentan seseorang maka akan semakin baik karena kecenderungan untuk berperilaku baik juga akan semakin besar. Responden merasa dirinya rentan terlihat dari banyaknya responden yang setuju apabila melakukan kontak langsung dengan penderita TB dapat tertular, merasa jika TB dapat menular melalui udara seperti batuk dan bersin 
Persepsi Keseriusan

Tabel 3

Frekuensi persepsi keseriusan

\begin{tabular}{lcc}
\hline $\begin{array}{c}\text { Persepsi } \\
\text { Keseriusan }\end{array}$ & Frekuensi & $\begin{array}{c}\text { Persentase } \\
(\%)\end{array}$ \\
\hline Kurang Baik & 18 & 29 \\
\hline Baik & 44 & 71 \\
\hline Total & $\mathbf{6 2}$ & $\mathbf{1 0 0}$ \\
\hline \multicolumn{1}{c}{ Tabel di atas } & menunjukkan
\end{tabular}

bahwa responden yang memilliki persepsi keseriusan baik lebih banyak sebesar $71 \%$ dibanding kurang baik. Hal tersebut dapat dipengaruhi oleh pengetahuan responden atau informasi tentang penyakit TB Paru dari lingkungan sekitar. Responden merasa serius dapat terlihat dari kuisioner yang telah dijawab, yaitu responden merasa malu terkena $\mathrm{TB}$, TB mengganggu aktivitas sehari-hari dan merasa bersalah apabila menularkan ke orang lain.

Persepsi Manfaat

Tabel 4

Frekuensi persepsi manfaat

\begin{tabular}{lcc}
\hline $\begin{array}{c}\text { Persepsi } \\
\text { Manfaat }\end{array}$ & Frekuensi & $\begin{array}{c}\text { Persentas } \\
\text { e (\%) }\end{array}$ \\
\hline Kurang Baik & 14 & 22,6 \\
\hline Baik & 48 & 77,4 \\
\hline Total & $\mathbf{6 2}$ & $\mathbf{1 0 0}$
\end{tabular}

Diketahui bahwa distribusi frekuensi responden berdasarkan persepsi manfaat terdapat $77,4 \%$ memiliki persepsi baik lebih banyak dibandingkan yang memiliki persespi manfaat kurang baik. Seseorang yang merasakan manfaat dalam melakukan pencegahan penularan TB Paru kecenderungan akan melakukan tindakan pencegahan lebih besar. Apabila seseorang merasa manfaat yang dirasa kecil dari melakukan suatu perilaku Diketahui bahwa responden yang memiliki persepsi kerentanan kurang baik dengan perilaku pencegahan kurang baik sebesar 36,3\%. Setelah dilakukan uji Chisquare dengan $p$-value sebesar 0,045 , yang Ho ditolak, artinya persepsi kerentanan mempengaruhi terhadap perilaku pencegahan penularan TB Paru. Persepsi kerentanan yang dirasakan responden tentang TB Paru, bahwa responden merasa TB Paru bukan penyakit yang menular dan tidak dapat menular melalui udara seperti percikan pencegahan maka kemungkinan untuk melakukan pencegahan juga akan semakin kecil.

Persepsi Hambatan

\section{Tabel 5}

Frekuensi persepsi hambatan

\begin{tabular}{|c|c|c|}
\hline $\begin{array}{c}\text { Persepsi } \\
\text { Keseriusan }\end{array}$ & Frekuensi & $\begin{array}{c}\text { Persentase } \\
(\%)\end{array}$ \\
\hline Kurang Baik & 37 & 59,7 \\
\hline Baik & 25 & 40,3 \\
\hline Total & 62 & 100 \\
\hline
\end{tabular}

bahwa responden yang memiliki persepsi hambatan baik $40,3 \%$ lebih banyak daripada yang memiliki persepsi hambatan baik. Hambatan atau rintangan merupakan faktor yang akan mempengaruhi seseorang dalam melakukan perubahan perilaku. Apabila seseorang merasa hambatan yang dihadapi besar ketika melakukan tindakan untuk perubahan perilaku maka kemungkinan orang tersebut untuk melakukan perubahan perilaku kecil, begitu sebaliknya.

Analisis Bivariat Hubungan persepsi kerentanan dengan perilaku pencegahan

Tabel 6

Hubungan antara persepsi kerentanan dengan perilaku pencegahan

\begin{tabular}{llllllll}
\hline \multirow{2}{*}{$\begin{array}{c}\text { Persepsi } \\
\text { Kerentanan }\end{array}$} & \multicolumn{6}{c}{ Perilaku Pencegahan } & \\
\cline { 2 - 7 } & Kurang Baik & Baik & & Total & $\begin{array}{c}\boldsymbol{p} \text { - } \\
\text { value }\end{array}$ \\
\cline { 2 - 7 } & $\mathbf{N}$ & $\mathbf{\%}$ & $\mathbf{N}$ & $\mathbf{\%}$ & $\mathbf{N}$ & $\mathbf{\%}$ & \\
\hline Kurang Baik & 4 & 36,3 & 7 & 63,6 & 11 & 100 & 0,045 \\
\hline Baik & 35 & 68,6 & 16 & 31,4 & 51 & 100 & \\
\hline Total & 39 & 63 & 23 & 37 & 62 & 100 & \\
\hline
\end{tabular}

dari batuk, bersin, ludah ataupun dahak, sehingga perilaku pencegahan yang dilakukan juga kurang baik seperti tidak menggunakan masker ketika di rumah, tidak menutup mulut ketika bersin atau batuk, dan meludah sembarangan. Kerentanan yang dirasakan rendah terhadap suatu penyakit dapat disebabkan karena kurangnya pengetahuan tentang penyakit.

Penelitian sejalan dengan penelitian yang dilakukan oleh Haryati (2017) yang memperoleh nilai $p$-value 
0,047 berdasarkan hasil uji Chi-square yang dapat diartikan bahwa ada hubungan yang signifikan antara persepsi kerentanan responden dengan perilaku pencegahan ISPA pneumonia.
Responden merasa rentan bahwa pneumonia merupakan penyakit berbahaya yang dapat menyerang balita dan dapat menular, sehingga responden melakukan tindakan pencegahan

\section{Hubungan persepsi keseriusan dengan perilaku pencegahan}

Tabel 7

Hubungan persepsi keseriusan dengan perilaku pencegahan

\begin{tabular}{|c|c|c|c|c|c|c|c|}
\hline \multirow{3}{*}{$\begin{array}{c}\text { Persepsi } \\
\text { Keseriusan }\end{array}$} & \multicolumn{6}{|c|}{ Perilaku Pencegahan } & \multirow{3}{*}{ p-value } \\
\hline & \multicolumn{2}{|l|}{$\begin{array}{l}\text { Kurang } \\
\text { Baik }\end{array}$} & \multicolumn{2}{|l|}{ Baik } & \multicolumn{2}{|l|}{ Total } & \\
\hline & $\mathbf{N}$ & $\%$ & $\mathbf{N}$ & $\%$ & $\mathbf{N}$ & $\%$ & \\
\hline Kurang Baik & 15 & 83,3 & 3 & 16,7 & 18 & 100 & 0,033 \\
\hline Baik & 24 & 54,5 & 20 & 45,5 & 44 & 100 & \\
\hline Total & 39 & 63 & 23 & 37 & 62 & 100 & \\
\hline
\end{tabular}

Berdasarkan tabel 7 dapat diketahui bahwa responden dengan persepsi keseriusan kurang baik memiliki perilaku pencegahan kurang baik sebesar $83,3 \%$. Hasil Analisa didapatkan nilai $p$ value sebesar 0,033. Maka, Ho ditolak yang artinya persepsi keseriusan mempengaruhi terhadap perilaku pencegahan penularan TB Paru.

Persepsi keseriusan sebagai perasaan tentang keseriusan dari suatu penyakit untuk mempertimbangkan dalam melakukan pengobatan atau tidak serta konsekuensi sosial yang harus diterima (Sarafino, 2006).

Sejalan dengan teori HBM apabila seseorang memiliki persepsi keseriusan yang tinggi terhadap ancaman suatu penyakit maka kemungkinan untuk mengambil suatu tindakan juga akan semakin lebih besar.
Menurut Rosenstock dalam Glanz (2006) bahwa kombinasi dari persepsi kerentanan dan persepsi keseriusan dapat disebut sebagai persepsi ancaman.

Persepsi keseriusan yang kurang baik dapat menyebabkan seseorang untuk berperilaku juga kurang baik karena pada penelitian ini responden merasa bahwa TB Paru merupakan penyakit yang tidak berbahaya dan bukan penyakit yang mematikan sehingga responden cenderung untuk tidak melakukan perilaku pencegahan yang baik. Keseriusan yang dirasakan menentukan dalam melakukan perilaku pencegahan terhadap penyakit tersebut. Persepsi serius seseorang terhadap suatu penyakit bukan hanya ditentukan oleh upaya pencegahan tetapi juga upaya pengobatan terutama apabila penyakit tersebut merupakan penyakit menular.

\section{Hubungan persepsi manfaat dengan perilaku pencegahan}

Tabel 8

Hubungan persepsi manfaat dengan perilaku pencegahan

\begin{tabular}{|c|c|c|c|c|c|c|c|}
\hline \multirow{3}{*}{$\begin{array}{l}\text { Persepsi } \\
\text { Manfaat }\end{array}$} & \multicolumn{6}{|c|}{ Perilaku Pencegahan } & \multirow{3}{*}{$p$-value } \\
\hline & $\begin{array}{l}\text { Kurang } \\
\text { Baik }\end{array}$ & & Bai & & Total & & \\
\hline & $\mathbf{N}$ & $\%$ & $\mathbf{N}$ & $\%$ & $\mathbf{N}$ & $\%$ & \\
\hline $\begin{array}{l}\text { Kurang } \\
\text { Baik }\end{array}$ & 12 & 85,7 & 2 & 14,3 & 14 & 100 & 0,045 \\
\hline Baik & 27 & 56,3 & 21 & 43,7 & 48 & 100 & \\
\hline Total & 39 & 63 & 23 & 37 & 62 & 100 & \\
\hline
\end{tabular}


Berdasarkan tabel 8 diketahui bahwa responden dengan persepsi manfaat kurang baik memiliki perilaku pencegahan kurang baik sebesar $85,7 \%$. Hasil Analisa didapatkan nilai $p$-value sebesar 0,045. Maka, Ho ditolak yang artinya persepsi manfaat mempengaruhi terhadap perilaku pencegahan penularan TB Paru.

Persepsi manfaat merupakan anggapan seseorang tentang nilai atau kegunaan dari perubahan perilaku baru yang dapat mengurangi risiko terserang penyakit (Jones and Bartlett, 2009).

Sesuai dengan teori Health Belief Model dalam Glanz (2008) bahwa rendahnya persepsi seseorang terhadap manfaat yang dirasakan dapat mempengaruhi kemauan seseorang dalam melakukan tindakan pencegahan. Hal tersebut disebabkan karena persepsi manfaat yang dirasakan merupakan pemrediksi dalam Health Belief Model yang melatarbelakangi tindakan dalam perubahan perilaku untuk mengurangi ancaman suatu penyakit.

Menurut Hochbaum (1958), penerimaan keseriusan dan kerentanan membentuk dorongan untuk bertindak tetapi masih tidak cukup untuk menentukan tindakan apa yang diambil. Maka gabungan antara manfaat dan biaya menciptakan kemungkinan seseorang untuk bertindak.

Seseorang akan cenderung berperilaku sehat ketika dia merasa perilaku tersebut bermanfaat untuk mengurangi risiko terserang suatu penyakit. Penelitian ini menunjukkan persepsi manfaat yang dirasakan responden masih kurang efektif dalam pencegahan penularan seperti tidur tidak terpisah, tidak menutup mulut ketika batuk bersin.

\section{Hubungan persepsi hambatan dengan perilaku pencegahan}

Tabel 9

Hubungan persepsi hambatan dengan perilaku pencegahan

\begin{tabular}{|c|c|c|c|c|c|c|c|}
\hline \multirow{3}{*}{$\begin{array}{l}\text { Persepsi } \\
\text { Hambatan }\end{array}$} & \multicolumn{6}{|c|}{ Perilaku Pencegahan } & \multirow[b]{2}{*}{$p$-value } \\
\hline & $\begin{array}{l}\text { Kuran } \\
\text { g Baik }\end{array}$ & & Bail & & Total & & \\
\hline & $\mathbf{N}$ & $\%$ & $\mathbf{N}$ & $\%$ & $\mathbf{N}$ & $\%$ & \\
\hline Kurang Baik & 25 & 67,6 & 12 & 32,4 & 37 & 100 & 0,355 \\
\hline Baik & 14 & 56 & 11 & 44 & 25 & 100 & \\
\hline Total & 39 & 63 & 23 & 27 & 62 & 100 & \\
\hline
\end{tabular}

Adapun hasil dari tabel di atas dapat diketahui bahwa responden dengan persepsi hambatan kurang baik memiliki perilaku pencegahan kurang baik sebesar $32,4 \%$. Hasil Analisa didapatkan nilai $p$ value sebesar 0,355. Maka, Ho diterima yang artinya persepsi hambatan tidak mempengaruhi terhadap perilaku pencegahan penularan TB Paru.

Salah satu konstruksi dari teori Health Belief Model adalah persepsi hambatan. Persepsi hambatan adalah potensi aspek negative dari tindakan kesehatan tertentu atau dapat juga sebagai halangan ketika akan melakukan perilaku yang direkomendasikan (Glanz, 2008).

Hambatan dalam penelitian ini seperti jarak, biaya, dan waktu untuk melakukan pencegahan dan pengobatan. Responden merasa bahwa beberapa hal tersebut tidak menjadi hambatan, seperti jarak rumah dengan pelayanan kesehatan, biaya tidak menjadi masalah karena responden merasa ingin sembuh dan didukung pemberian obat TB secara gratis, waktu dan kesibukan seperti pekerjaan tidak menjadi hambatan bagi responden untuk melakukan pengobatan.

\section{KESIMPULAN}

Berdasarkan hasil penelitian tentang pembahasan hubungan persepsi dengan perilaku pencegahan TB Paru di Puskesmas Perak Timur tahun 2019, diperoleh kesimpulan sebagai berikut: 
1. Terdapat hubungan antara persepsi kerentanan dengan perilaku pencegahan penularan TB Paru.

2. Terdapat hubungan antara persepsi keseriusan dengan perilaku pencegahan penularan TB Paru.

3. Terdapat hubungan antara persepsi manfaat dengan perilaku pencegahan penularan TB Paru.

4. Tidak terdapat hubungan antara persepsi hambatan dengan perilaku pencegahan penularan TB Paru.

\section{SARAN}

1. Bagi petugas kesehatan sebaiknya memberikan sosialiasi dan penyuluhan lebih intensif bagi penderita TB Paru dan selain penderita TB Paru terutama tentang penyakit TB Paru sehingga masyarakat untuk meningkatkan pengetahuan dan agar tidak salah persepsi sehingga dapat melakukan pencegahan penularan TB Paru.

2. Bagi peneliti diharap dapat menerapkan ilmu kesehatan yang telah didapat dalam perilaku pencegahan penuluaran penyakit.

3. Bagi peneliti lain diharapkan dapat mengembangkan tentang perilaku pencegahan TB Paru dengan teori perilaku selain Health Belief
Modeldan dikarenakan penelitian ini menggunakan metode kuisioner sehingga bagi peneliti selanjutnya dapat menggunakan metode observasi untuk menilai perilaku pencegahan penularan TB Paru.

\section{DAFTAR PUSTAKA}

Dinas Kesehatan Kota Surabaya. 2016. Profil Dinas Kesehatan Kota Surabaya. Surabaya: Dinas Kesehatan Kota Surabaya

Dinas Kesehatan Pemerintah Kota Surabaya. 2017. Profil Kesehatan 2017. Surabaya

Haryati, A D. 2017. Hubungan Persepsi Ibu Dengan Perilaku Pencegahan Infeksi Saluran Pernafasan Akut (Ispa) Pneumonia Pada Balita Di Puskesmas Kenten Kota Palembang Tahun 2017. Universitas Sriwijaya: Program Studi Ilmu Kesehatan Masyarakat Hochbaum, G.M. 1958. Public Participation in Medical Screening programs: A Socio-psychological Study (Public Health Service Publication No. 572). Washington, DC: Government Printing Office.

Sarafino, Edward P. 2006. Health Psychology: Biopsychosocial Interaction Fifth Edition. New York. John Wiley and Sons, Inc. 